This item was submitted to Loughborough's Research Repository by the author.

Items in Figshare are protected by copyright, with all rights reserved, unless otherwise indicated.

\title{
Improvement in blood pressure after short-term inorganic nitrate supplementation is attenuated in cigarette smokers compared to non- smoking controls
}

\section{PLEASE CITE THE PUBLISHED VERSION}

http://dx.doi.org/10.1016/j.niox.2016.10.002

\section{PUBLISHER}

(C) Elsevier

\section{VERSION}

AM (Accepted Manuscript)

\section{PUBLISHER STATEMENT}

This work is made available according to the conditions of the Creative Commons Attribution-NonCommercialNoDerivatives 4.0 International (CC BY-NC-ND 4.0) licence. Full details of this licence are available at: https://creativecommons.org/licenses/by-nc-nd/4.0/

\section{LICENCE}

CC BY-NC-ND 4.0

\section{REPOSITORY RECORD}

Bailey, Stephen J., Jamie R. Blackwell, Lee J. Wylie, Terezia Holand, Paul G. Winyard, and Andrew M. Jones. 2019. "Improvement in Blood Pressure After Short-term Inorganic Nitrate Supplementation Is Attenuated in Cigarette Smokers Compared to Non-smoking Controls". figshare. https://hdl.handle.net/2134/23175. 


\section{Improvement in blood pressure after short-term inorganic nitrate supplementation is attenuated in cigarette smokers compared to non-smoking controls}

Stephen J. Baileya, Jamie R. Blackwell ${ }^{a}$, Lee J. Wylie ${ }^{a}$, Terezia Holland $^{\mathrm{b}}$, Paul G. Winyard ${ }^{\mathrm{b}}$ and Andrew M. Jones ${ }^{\mathrm{a}}$

${ }^{a}$ Sport and Health Sciences, College of Life and Environmental Sciences and ${ }^{\mathrm{b}}$ University of Exeter Medical School, St. Luke's Campus, University of Exeter, Heavitree Road, Exeter, UK.

Address for Correspondence:

Stephen J Bailey PhD

E-mail: S.Bailey2@lboro.ac.uk

School of Sport, Exercise and Health Sciences

Loughborough University

Ashby Road

Loughborough

Leicestershire LE11 3TU

Tel: +44 (0) 1509226433

Fax: +44 (0) 150922630 


\section{ABSTRACT}

Dietary supplementation with inorganic nitrate $\left(\mathrm{NO}_{3}{ }^{-}\right)$has been reported to improve cardiovascular health indices in healthy adults. Cigarette smoking increases circulating thiocyanate $\left(\mathrm{SCN}^{-}\right)$, which has been suggested to competitively inhibit salivary nitrate $\left(\mathrm{NO}_{3}{ }^{-}\right)$ uptake, a rate-limiting step in dietary $\mathrm{NO}_{3}{ }^{-}$metabolism. Therefore, this study tested the hypothesis that dietary $\mathrm{NO}_{3}{ }^{-}$supplementation would be less effective at increasing the circulating plasma nitrite concnetration $\left(\left[\mathrm{NO}_{2}{ }^{-}\right]\right)$and lowering blood pressure in smokers (S) compared to non-smokers (NS). Nine healthy smokers and eight healthy non-smoking controls reported to the laboratory at baseline (CON) and following six day supplementation periods with $140 \mathrm{ml} \cdot$ day $^{-1} \mathrm{NO}_{3}{ }^{-}$-rich $\left(8.4 \mathrm{mmol} \mathrm{NO}_{3}{ }^{-} \cdot\right.$ day $^{-1}$; NIT) and $\mathrm{NO}_{3}{ }^{-}$-depleted $(0.08$ mmol $\mathrm{NO}_{3}{ }^{-} \cdot$ day $^{-1}$; PLA) beetroot juice in a cross-over experiment. Plasma and salivary [SCN$\left.{ }^{-}\right]$were elevated in smokers compared to non-smokers in all experimental conditions $(P<0.05)$. Plasma and salivary $\left[\mathrm{NO}_{3}{ }^{-}\right]$and nitrite $\left(\left[\mathrm{NO}_{2}{ }^{-}\right]\right)$were elevated in the NIT condition compared to CON and PLA conditions in smokers and non-smokers $(P<0.05)$. However, the change in salivary $\left[\mathrm{NO}_{3}{ }^{-}\right]$(S: $3.5 \pm 2.1$ vs. NS: $\left.7.5 \pm 4.4 \mathrm{mM}\right)$, plasma $\left[\mathrm{NO}_{3}{ }^{-}\right](\mathrm{S}: 484 \pm 198$ vs. NS: $802 \pm 199 \mu \mathrm{M}$ ) and plasma [NO$\left.{ }_{2}^{-}\right]$(S: $218 \pm 128$ vs. NS: $559 \pm 419 \mathrm{nM}$ ) between the CON and NIT conditions was lower in the smokers compared to the non-smokers $(P<0.05)$. Salivary $\left[\mathrm{NO}_{2}{ }^{-}\right]$increased above CON to a similar extent with NIT in smokers and nonsmokers $(P>0.05)$. Systolic blood pressure was lowered compared to PLA with NIT in nonsmokers $(P<0.05)$, but not smokers $(P>0.05)$. These findings suggest that dietary $\mathrm{NO}_{3}{ }^{-}$ metabolism is compromised in smokers leading to an attenuated blood pressure reduction compared to non-smokers after $\mathrm{NO}_{3}{ }^{-}$supplementation. These observations may provide novel insights into the cardiovascular risks associated with cigarette smoking and suggest that this population may be less likely to benefit from improved cardiovascular health if they increase dietary $\mathrm{NO}_{3}{ }^{-}$intake.

Key Words: nitric oxide; thiocyanate; cardiovascular health; tobacco; fatigue 


\section{INTRODUCTION}

Cardiovascular disease is the leading cause of mortality in developed countries and costs the global economy approximately US\$3.7 trillion per annum [1]. As such, interventions that can lower cardiovascular disease morbidity will be of epidemiological and economic importance. It has long been appreciated that a diet rich in fruit and vegetables lowers the risk of developing cardiovascular diseases and the incidence of adverse cardiovascular events such as stroke, heart failure and coronary heart disease [2,3]. Consequently, there are numerous government-driven initiatives to increase fruit and vegetable consumption including the Dietary Approaches to Stop Hypertension (DASH) diet in the United States of America [4], the 5-A-Day diet in the United Kingdom [5] and variations of this latter diet in countries within the European Union [6].

It has been suggested that the cardio-protective effects of diets rich in fruit and vegetables might be linked to their high inorganic nitrate $\left(\mathrm{NO}_{3}^{-}\right)$content [7-9]. Vegetable consumption accounts for $60-80 \%$ of dietary $\mathrm{NO}_{3}{ }^{-}$intake [10] with leafy-green vegetables (e.g., spinach and lettuce varieties) and beetroot being particularly rich in $\mathrm{NO}_{3}{ }^{-}$[7]. It has been reported that consuming 5 portions of $\mathrm{NO}_{3}{ }^{-}$-rich vegetables for 7 days, which provided a daily $\mathrm{NO}_{3}{ }^{-}$ intake of $\sim 317 \mathrm{mg}$ (5.1 mmol), lowered systolic blood pressure, whereas a control diet where participants avoided $\mathrm{NO}_{3}{ }^{-}$-rich vegetables, resulting in a daily $\mathrm{NO}_{3}{ }^{-}$intake of $\sim 8 \mathrm{mg}(0.1$ mmol), did not [9]. Increased dietary $\mathrm{NO}_{3}{ }^{-}$intake in the form of $\mathrm{NO}_{3}{ }^{-}$-rich beetroot [11-13] or spinach [14,15] supplementation alone has also been shown to lower resting blood pressure. These findings are consistent with the emerging body of evidence to support improved vascular health following dietary $\mathrm{NO}_{3}{ }^{-}$supplementation (4-16 mmol-day ${ }^{-1}$ ) in younger [11-13] and older [16,17] normotensive adults, and in individuals with hypertension [18], peripheral artery disease [19] and heart failure [20]. Therefore, enriching the diet with $\mathrm{NO}_{3}{ }^{-}$, at a dose that can be readily achieved by a diet high in vegetables $[4,7,9]$, might represent a practical and cost-effective intervention to lower cardiovascular disease morbidity and mortality.

After oral ingestion, approximately $25 \%$ of $\mathrm{NO}_{3}{ }^{-}$passes into the entero-salivary circulation [21]. Subsequently, $\mathrm{NO}_{3}{ }^{-}$is concentrated and delivered within saliva to the oral cavity where facultative microflora reduce $\mathrm{NO}_{3}{ }^{-}$to nitrite $\left(\mathrm{NO}_{2}{ }^{-}\right)$[21-25]. $\mathrm{NO}_{2}{ }^{-}$-rich saliva is then ingested 
and $\mathrm{NO}_{2}{ }^{-}$is further reduced to nitric oxide (NO) and other reactive nitrogen intermediates in the acidic environment of the stomach [26-27]. It is also clear that a portion (in the $\mathrm{nM}$ range) of the ingested $\mathrm{NO}_{2}{ }^{-}$passes into the systemic circulation [24] where it can impact vascular function directly $[28,29]$ or through its subsequent reduction to NO via a number of $\mathrm{NO}_{2}{ }^{-}$reductases [30]. Although mammalian tissues have the capacity to directly metabolise $\mathrm{NO}_{3}{ }^{-}$[34], the entero-salivary delivery of $\mathrm{NO}_{3}{ }^{-}$to the oral cavity and its subsequent reduction to $\mathrm{NO}_{2}{ }^{-}$by lingual anaerobes, are key rate limiting steps of $\mathrm{NO}_{3}{ }^{-}$metabolism in mammals [35]. There is evidence to suggest that the uptake of $\mathrm{NO}_{3}{ }^{-}$into the salivary circulation occurs in competition with perchlorate, thiocyanate $\left(\mathrm{SCN}^{-}\right)$and iodide [36]. Therefore, increased exposure to perchlorate, $\mathrm{SCN}^{-}$or iodide may interfere with dietary $\mathrm{NO}_{3}{ }^{-}$metabolism and might subsequently blunt the improvements in vascular health that have typically been observed after increased dietary $\mathrm{NO}_{3}{ }^{-}$intake.

Cigarette smoking is a major risk factor for cardiovascular disease morbidity and mortality [37-39], and a leading cause of preventable death worldwide [38,40]. In spite of global government initiatives to facilitate smoking cessation, there are still an estimated 1 billion smokers worldwide [41]. Cigarette smoke contains over 7000 noxious chemicals, including cyanide [38]. Following consumption, cyanide is rapidly detoxified to thiocyanate (SCN$\left.{ }^{-}\right)$ via transsulfuration reactions catalysed by the enzymes, thiosulfate sulfotransferase (rhodanase) and 3-mercaptopyruvate sulfurtransferase [42]. Consequently, cigarette smokers have elevated plasma and salivary [ $\left.\mathrm{SCN}^{-}\right]$compared to non-smoking controls [e.g., 43]. Importantly, and consistent with a competitive inhibition of salivary $\mathrm{NO}_{3}{ }^{-}$uptake by $\mathrm{SCN}^{-}$ [36], it has been reported that salivary $\left[\mathrm{NO}_{3}{ }^{-}\right]$is lower in cigarette smokers after $\mathrm{NO}_{3}{ }^{-}$ ingestion, compared to non-smoking controls [44,45]. However, in spite of a lower salivary $\left[\mathrm{NO}_{3}{ }^{-}\right]$after $\mathrm{NO}_{3}{ }^{-}$ingestion in smokers, the increase in salivary $\left[\mathrm{NO}_{2}{ }^{-}\right]$was not different between the smokers and non-smokers [44]. It is therefore unclear whether cigarette smoking interferes with the increases in plasma $\left[\mathrm{NO}_{2}^{-}\right]$and the associated reduction of blood pressure that has been observed following dietary $\mathrm{NO}_{3}{ }^{-}$ingestion in non-smokers $[12,13,31,33]$. Further research is required to elucidate the effects of cigarette smoking on dietary $\mathrm{NO}_{3}{ }^{-}$ metabolism and its implications for vascular health. If dietary $\mathrm{NO}_{3}{ }^{-}$metabolism is indeed perturbed by cigarette smoking, this may provide new insights into the mechanisms by which cigarette smoking increases cardiovascular disease morbidity. 
The purpose of this study was to assess the effects of six days dietary $\mathrm{NO}_{3}{ }^{-}$supplementation on plasma and salivary $\left[\mathrm{NO}_{3}{ }^{-}\right],\left[\mathrm{NO}_{2}^{-}\right]$and $\left[\mathrm{SCN}^{-}\right]$and resting blood pressure in smokers and non-smoking controls. It was hypothesized that the increases in salivary $\left[\mathrm{NO}_{3}{ }^{-}\right]$, plasma $\left[\mathrm{NO}_{3}{ }^{-}\right]$and plasma $\left[\mathrm{NO}_{2}{ }^{-}\right]$, but not salivary $\left[\mathrm{NO}_{2}{ }^{-}\right]$, after dietary $\mathrm{NO}_{3}{ }^{-}$supplementation would be attenuated in cigarette smokers compared to non-smoking controls. It was also hypothesised that dietary $\mathrm{NO}_{3}{ }^{-}$supplementation would lower blood pressure in non-smokers, but not in smokers.

\section{MATERIALS AND METHODS}

\subsection{Subjects}

We recruited nine cigarette smokers ( 5 males, mean \pm SD, age $24 \pm 7$ yr, body mass index 23 $\pm 2 \mathrm{~kg} \cdot \mathrm{m}^{2}$; smoking history $7 \pm 6$ pack years) and eight age- and BMI-matched non-smoking controls (4 males, mean $\pm \mathrm{SD}$, age $24 \pm 5 \mathrm{yr}$, body mass index $23 \pm 4 \mathrm{~kg} \cdot \mathrm{m}^{2}$ ) from the University staff and student communities to participate in this study. Both the smokers [forced vital capacity (FVC) $4.68 \pm 1.02 \mathrm{~L}$; forced expiratory volume in 1-s $\left(\mathrm{FEV}_{1}\right) 4.26 \pm$ $0.99 \mathrm{~L} ; \mathrm{FEV}_{1} / \mathrm{FVC} 91 \pm 6$ \%] and non-smokers (FVC, $4.17 \pm 0.76 \mathrm{~L} ; \mathrm{FEV}_{1}, 3.64 \pm 0.57 \mathrm{~L}$; $\mathrm{FEV}_{1} / \mathrm{FVC} 88 \pm 5 \%$ ] exhibited normal resting pulmonary function and had a similar level of habitual physical activity, as assessed by the Baecke et al. [46] questionnaire (smokers, $7.2 \pm$ 1.7; non-smokers $7.2 \pm 1.7$ ), upon recruitment to the study. All procedures employed in this study were approved by the Institutional Research Ethics Committee and subjects gave their written informed consent to participate prior to the commencement of the study, after the experimental procedures, associated risks, and potential benefits of participation had been explained. Subjects were instructed to arrive at each laboratory testing session in a rested and fully hydrated state, at least $3 \mathrm{~h}$ postprandial. Since the reduction of $\mathrm{NO}_{3}{ }^{-}$to $\mathrm{NO}_{2}{ }^{-}$in the oral cavity is compromised by antibacterial mouthwash [47], subjects were required to refrain from mouthwash use for the duration of the study. Each subject was also asked to avoid consumption of nitrate-rich foods for the duration of the study, and from caffeine and alcohol ingestion 6 and $24 \mathrm{~h}$ before each test, respectively. All subjects were instructed to maintain their habitual physical activity pattern for the duration of the study, and to avoid strenuous exercise in the $24 \mathrm{~h}$ preceding the testing sessions. Smokers were asked to maintain their habitual smoking patterns for the duration of the study, but were required to abstain from 
smoking for $3 \mathrm{~h}$ before each testing session. All tests were performed at the same time of day ( \pm 2 hours).

\subsection{Supplementation Procedures}

All subjects were required to report to the laboratory on three occasions over a 3-4 week period. Subjects did not undergo dietary supplementation prior to their first visit to the laboratory (the control condition; CON). Subjects were asked to record their food and beverage consumption on the day of the CON test and for the 5 days preceding this test and to replicate this prior to the subsequent trials. After completing the CON trial, subjects were randomly assigned to receive six days of supplementation with either $\mathrm{NO}_{3}{ }^{-}$-rich (NIT) or $\mathrm{NO}_{3}{ }^{-}$-depleted beetroot juice as a placebo (PLA) as part of a double-blind, cross-over experimental design. In the NIT and PLA conditions, subjects ingested $70 \mathrm{ml}$ of concentrated beetroot juice containing 4.2 and $0.04 \mathrm{mmol} \mathrm{NO}_{3}{ }^{-}$, respectively, in the morning and evening over the first five days of supplementation. Subjects ingested $140 \mathrm{ml}$ of beetroot juice two hours before reporting to the laboratory on day six of NIT and PLA supplementation period. This was selected to coincide with the peak plasma $\left[\mathrm{NO}_{2}{ }^{-}\right]$attained following ingestion of 8.4 mmol $\mathrm{NO}_{3}{ }^{-}$[13]. A 7-10 day washout separated the supplementation periods.

\subsection{Measurements}

\subsubsection{Expired carbon monoxide and resting respiratory function}

Upon arrival at the laboratory the carbon monoxide (CO) content of subjects' expired air was assessed in a standing position using a hand-held $\mathrm{CO}$ analyzer (Micro ${ }^{+}$Smokerlyzer, Bedfont Scientific Ltd, Kent, UK). For this assessment subjects were instructed to inhale to total lung capacity and then exhale slowly into the CO analyzer until they attained residual volume. Three manoeuvres were completed with the highest CO measurement used for analysis. Subjects then completed three FVC manoeuvres using a hand-held micro spirometer (Micro Plus, Micro Medical Ltd, Kent, UK) for the assessment of resting respiratory function (FVC, $\mathrm{FEV}_{1}$ and $\mathrm{FEV}_{1} / \mathrm{FVC}$ ). For this assessment subjects were instructed to inhale to the total lung capacity and then exhale as quickly and forcefully as possible into the micro spirometer until they attained residual volume. The data from the manoeuvre that produced the highest FVC were used for analysis. Subjects were fitted with a nose clip during all these measurements to prevent the expiration of air through the nasal passage. 


\subsubsection{Blood Pressure}

Subjects were required to rest supine for $10 \mathrm{~min}$ in an isolated room. Thereafter, blood pressure of the brachial artery was measured whilst the subject was supine using an automated sphygmomanometer (Dinamap Pro, GE Medical Systems, Tampa, USA). Five measurements were taken and the mean of the measurements 2-5 was used for analysis.

\subsubsection{Blood and saliva collection}

Venous blood samples were drawn into $6 \mathrm{~mL}$ lithium-heparin tubes (Sarstedt, Leicester, UK). Samples were centrifuged at 4,000 rpm and $4^{\circ} \mathrm{C}$ for $10 \mathrm{~min}$, within $1 \mathrm{~min}$ of collection. Plasma was subsequently extracted and immediately frozen at $-80^{\circ} \mathrm{C}$ for later analysis of $\left[\mathrm{NO}_{2}{ }^{-}\right],\left[\mathrm{NO}_{3}{ }^{-}\right]$and $\left[\mathrm{SCN}^{-}\right]$. Unstimulated saliva samples $(\sim 3 \mathrm{~mL})$ were collected into $30 \mathrm{~mL}$ universal containers and $1 \mathrm{~mL}$ aliquots were frozen at $-80^{\circ} \mathrm{C}$ for later analysis of $\left[\mathrm{NO}_{2}{ }^{-}\right]$, $\left[\mathrm{NO}_{3}{ }^{-}\right]$and $\left[\mathrm{SCN}^{-}\right]$.

\subsection{Data analysis procedures}

\subsection{1 $\left[\mathrm{NO}_{3}{ }^{-}\right]$and $\left[\mathrm{NO}_{2}{ }^{-}\right]$determination}

All glassware, utensils, and surfaces were rinsed with deionized water to remove residual NO prior to $\left[\mathrm{NO}_{2}^{-}\right]$and $\left[\mathrm{NO}_{3}^{-}\right]$analysis. Plasma samples were deproteinized using zinc sulfate/sodium hydroxide precipitation prior to determination of $\left[\mathrm{NO}_{3}{ }^{-}\right]$. Firstly, $500 \mu \mathrm{L}$ of $0.18 \mathrm{~N} \mathrm{NaOH}$ was added to $100 \mu \mathrm{L}$ of sample followed by $5 \mathrm{~min}$ incubation at room temperature. Subsequently, samples were treated with $300 \mu \mathrm{L}$ aqueous $\mathrm{ZnSO}_{4}(5 \% \mathrm{w} / \mathrm{v})$ and vortexed for 30 seconds before undergoing an additional 10 min incubation period at room temperature. Samples were then centrifuged at 4,000 rpm for $5 \mathrm{~min}$, and the supernatant was removed for subsequent analysis. The $\left[\mathrm{NO}_{3}{ }^{-}\right]$of the deproteinized plasma sample was determined by its reduction to $\mathrm{NO}$ in the presence of $0.8 \%(\mathrm{w} / \mathrm{v}) \mathrm{VCl}_{3}$ in $1 \mathrm{M} \mathrm{HCl}$ within an air-tight purging vessel. Plasma samples were introduced to the vessel via $100 \mu \mathrm{L}$ injections into the septum at the top of the vessel. The spectral emission of electronically excited nitrogen dioxide, derived from the reaction of NO with ozone, was detected by a thermoelectrically cooled, red-sensitive photomultiplier tube housed in a Sievers gas-phase chemiluminescence nitric oxide analyzer (Sievers NOA 280i. Analytix Ltd, Durham, UK). The $\left[\mathrm{NO}_{3}{ }^{-}\right]$was determined by plotting signal $(\mathrm{mV})$ area against a calibration plot of sodium nitrate standards. The $\left[\mathrm{NO}_{2}^{-}\right]$of the undiluted (non-deproteinized) plasma was determined by its reduction to $\mathrm{NO}$ in the presence of glacial acetic acid and aqueous $\mathrm{NaI}(4 \% \mathrm{w} / \mathrm{v})$, and calibrated using sodium nitrite standards. After thawing at room temperature, saliva samples 
were centrifuged for $10 \mathrm{~min}$ at $14000 \mathrm{rpm}$ and the supernatant was removed for subsequent analysis. The supernatant was diluted 100 fold with deionized water and $\left[\mathrm{NO}_{3}{ }^{-}\right]$and $\left[\mathrm{NO}_{2}{ }^{-}\right]$ were determined from $50 \mu \mathrm{L}$ injections using the same reagents describe above for the plasma analyses.

\subsection{2 [SCN'] determination}

Plasma and salivary [ $\left.\mathrm{SCN}^{-}\right]$were measured in duplicate using the procedures described by Tsuge et al. [43]. Briefly, $300 \mu \mathrm{L}$ of plasma was treated with $200 \mu \mathrm{L}$ of trichloroacetic acid $(25 \% \mathrm{w} / \mathrm{v})$ and centrifuged for $10 \mathrm{~min}$ at $14000 \mathrm{rpm}$. The supernatant was then removed for subsequent analysis. $50 \mu \mathrm{L}$ of sample, $15 \mu \mathrm{L} \times 1$ M of ice-cold potassium hydrogen phosphate solution ( $\mathrm{pH}$ 5.5), $5 \mu \mathrm{L}$ of $5 \mathrm{M} \mathrm{NaOH}$ solution, and $10 \mu \mathrm{L}$ of $6.25 \mathrm{mg} / \mathrm{ml}$ chloramine T solution were added to a 96-well microtiter plate (Sterilin Ltd., Caerphilly, UK) and incubated on ice for 2 min. Subsequently, $120 \mu \mathrm{L}$ of cyanoline blue solution $(0.27 \%$ $\mathrm{w} / \mathrm{v}$ ) was added to the microtiter plate and the plate was incubated for $20 \mathrm{~min}$ at room temperature. Following incubation, sample absorbance was measured at $620 \mathrm{~nm}$ using a microplate reader (EnSpire 2300, Perkin Elmer, Hamburg, Germany). Thawed saliva samples were centrifuged for $10 \mathrm{~min}$ at $14000 \mathrm{rpm}$ and the supernatant was removed for subsequent analysis. Samples were diluted 25 fold, and $40 \mu \mathrm{L}$ of the diluted sample was added to a 96-well microtiter plate in addition to $20 \mu \mathrm{L}$ of $1 \mathrm{M}$ potassium phosphate buffer solution and $20 \mu \mathrm{L}$ of $6.25 \mathrm{mg} / \mathrm{ml}$ choramine T solution, and incubated on ice for $2 \mathrm{~min} .140$ $\mu \mathrm{L}$ of cyanoline blue solution $(0.27 \% \mathrm{w} / \mathrm{v})$ in pyridine-water $(1: 5, \mathrm{v} / \mathrm{v})$ was added to the microtiter plate followed by $20 \mathrm{~min}$ incubation at room temperature. Following incubation, sample absorbance was measured at $620 \mathrm{~nm}$ using a microplate reader.

\subsection{Statistics}

A two-way (treatment by group) ANOVA with repeated measures for treatment (CON, PLA and NIT) was employed to determine the effects of the different dietary interventions on plasma and salivary $\left[\mathrm{NO}_{3}{ }^{-}\right]$and $\left[\mathrm{NO}_{2}{ }^{-}\right]$in the smokers and non-smokers. Where the analysis revealed a significant main or interaction effect, simple follow-up contrasts were employed to determine the origin of such effects. Paired samples $t$-tests were employed to compare the effects of PLA and NIT on blood pressure variables. Pearson's product moment correlation coefficient was used to assess the relationship between changes in variables across conditions in the smokers and non-smokers. All data are presented as mean \pm SD unless otherwise indicated. Statistical significance was accepted when $P<0.05$. 


\section{RESULTS}

The PLA and BR supplements administered in this study were well tolerated by all subjects with no negative side effects reported. Subjects self-reported that they consumed all doses of the supplement for each experimental condition and that their diet and physical activity patterns were consistent across all the dietary interventions. Smokers confirmed that their smoking habits remained consistent across the experimental testing period and that they avoided smoking a cigarette for at least 3 hours before each experimental testing session as instructed. There was a main effect for group on expired [CO] $(P<0.01)$ with smokers exhibiting a higher expired [CO] than non-smokers in CON (6 \pm 3 ppm vs. $2 \pm 1$ ppm), PLA (6 \pm 2 ppm vs. $2 \pm 1$ ppm) and NIT (6 \pm 3 ppm vs. $2 \pm 0$ ppm; $P<0.01$ for all comparisons), with no differences in expired [CO] between treatments in either the smokers or non-smokers ( $P>0.05$ for all comparisons).

\subsection{Salivary and plasma [SCN$\left.{ }^{-}\right]$}

Salivary [SCN${ }^{-}$] was higher in smokers than non-smokers in CON, PLA and NIT $(P<0.05$ for all comparisons; Figure 1). Salivary [SCN$\left.{ }^{-}\right]$was lower in NIT than CON and PLA in both smokers and non-smokers ( $P<0.05$ for all comparisons). Plasma [ $\left.\mathrm{SCN}^{-}\right]$was higher in smokers than non-smokers in CON, PLA and NIT ( $P<0.05$ for all comparisons). There were no between-treatment differences in either the smoking or non-smoking groups $(P>0.05$ for all comparisons).

\subsection{Salivary and plasma $\left[\mathrm{NO}_{3}{ }^{-}\right]$and $\left[\mathrm{NO}_{2}{ }^{-}\right]$}

There was a group $\times$ treatment interaction effect for salivary $\left[\mathrm{NO}_{3}{ }^{-}\right](P<0.05)$. Further analyses revealed that salivary $\left[\mathrm{NO}_{3}{ }^{-}\right]$was higher than CON and PLA in NIT in both smokers and non-smokers ( $P<0.01$ for all comparisons; Figure 2), with a lower salivary $\left[\mathrm{NO}_{3}{ }^{-}\right]$ observed in smokers compared to non-smokers in NIT $(P<0.05)$. A negative correlation was observed between the salivary $\left[\mathrm{SCN}^{-}\right]$in the $\mathrm{CON}$ condition and the change in the salivary $\left[\mathrm{NO}_{3}{ }^{-}\right]$between the CON and NIT conditions in the smokers ( $r=-0.78, P<0.01$; Figure 3 ) There was a main effect for treatment on salivary $\left[\mathrm{NO}_{2}^{-}\right](P<0.01)$ with salivary $\left[\mathrm{NO}_{2}^{-}\right]$being higher than CON and PLA in NIT in both smokers and non-smokers $(P<0.01$ for all comparisons, Figure 2). However, there were no differences between smokers and nonsmokers in any of the experimental conditions $(P>0.05)$. 
There was a group $\times$ treatment interaction effect for both plasma $\left[\mathrm{NO}_{3}{ }^{-}\right]$and $\left[\mathrm{NO}_{2}{ }^{-}\right]$ $(P<0.01)$. Plasma $\left[\mathrm{NO}_{3}{ }^{-}\right]$and $\left[\mathrm{NO}_{2}{ }^{-}\right]$were not different between smokers and non-smokers in CON and PLA $(P>0.05)$. While plasma $\left[\mathrm{NO}_{3}{ }^{-}\right]$and $\left[\mathrm{NO}_{2}{ }^{-}\right]$were higher than CON and PLA with NIT in both smokers and non-smokers $(P<0.01)$, plasma $\left[\mathrm{NO}_{3}{ }^{-}\right]$and $\left[\mathrm{NO}_{2}{ }^{-}\right]$were lower in smokers than non-smokers in NIT $(P<0.01$, Figure 2).

\subsection{Blood pressure}

Systolic, diastolic and mean arterial blood pressures were not different between the smokers and non-smokers in the NIT and PLA conditions ( $P>0.05$, Table 1$)$. Systolic blood pressure was lowered in the NIT condition compared to PLA in non-smokers $(P<0.05)$, but not smokers ( $P>0.05$; Figure 4). There were no differences in diastolic blood pressure or mean arterial pressure between the smoking and non-smoking groups in the PLA and NIT conditions $(P>0.05)$. There was a negative correlation between the change in in plasma $\left[\mathrm{NO}_{2}{ }^{-}\right.$ ] and the change in systolic blood pressure $(r=-0.71, P<0.05)$, but not diastolic $(r=-0.17)$ or mean arterial blood pressure $(r=-0.36)$ in the non-smokers between the PLA and NIT trials $(P>0.05)$. There were no correlations between the change in plasma $\left[\mathrm{NO}_{2}^{-}\right]$and the changes in systolic $(r=0.25)$ diastolic $(r=0.08)$ and mean arterial $(r=0.24)$ blood pressure in the smokers between the PLA and NIT trials $(P>0.05)$.

\section{DISCUSSION}

The important novel findings from this study are that, despite consuming the same absolute $\mathrm{NO}_{3}{ }^{-}$dose, the increases in salivary $\left[\mathrm{NO}_{3}{ }^{-}\right]$, plasma $\left[\mathrm{NO}_{3}{ }^{-}\right]$and plasma $\left[\mathrm{NO}_{2}{ }^{-}\right]$were essentially halved in smokers compared to non-smokers, and blood pressure was only improved in non-smokers. These findings are important because they suggest that cigarette smokers may not derive the same vascular benefits, compared to age-, BMI- and activitymatched non-smoking controls, if they increase dietary $\mathrm{NO}_{3}{ }^{-}$intake. Therefore, our findings might provide novel insights into the potential risk factors that predispose cigarette smokers to increased cardiovascular disease morbidity.

In the CON condition, where participants did not receive any dietary supplementation, plasma and salivary $\left[\mathrm{SCN}^{-}\right]$were $122 \%$ and $89 \%$ higher in the smokers compared to the nonsmokers. Plasma and salivary $\left[\mathrm{SCN}^{-}\right]$were also higher in the smokers compared to the non- 
smokers after PLA and NIT supplementation. Several previous studies have reported increased plasma and salivary [ $\left.\mathrm{SCN}^{-}\right]$in smokers compared to non-smokers $[43,48]$. It is known that cigarette smoke contains cyanide [38] and that the increase in systemic [SCN${ }^{-}$] in cigarette smokers is consequent to cyanide detoxification facilitated by the enzymes, thiosulfate sulfotransferase (rhodanase) and 3-mercaptopyruvate sulfurtransferase [42]. Consequently, salivary/plasma [ $\left.\mathrm{SCN}^{-}\right]$has been recommended as an objective marker of smoking status $[43,49]$. However, it has been suggested that expired [CO] might be a more sensitive bio-marker of smoking status than salivary/plasma [SCN$\left.{ }^{-}\right]$[50-52]. Expired [CO] was $200 \%$ higher in the smokers compared to the non-smokers in all experimental conditions in this study. Taken together, these findings confirm that the participants in our smoking group were indeed active smokers, and that they consistently adhered to the requirement to abstain from smoking for $3 \mathrm{~h}$ before each testing session.

In line with previous studies, salivary and plasma $\left[\mathrm{NO}_{3}^{-}\right]$and $\left[\mathrm{NO}_{2}^{-}\right]$were increased following dietary $\mathrm{NO}_{3}{ }^{-}$supplementation in this study [47,53]. However, despite oral consumption of the same absolute $\mathrm{NO}_{3}{ }^{-}$dose $(8.4 \mathrm{mmol})$, the increase in salivary $\left[\mathrm{NO}_{3}{ }^{-}\right]$ above CON in the smokers $(3510 \mu \mathrm{M})$ was only $48 \%$ of that observed in the non-smokers $(7289 \mu \mathrm{M})$. These findings are consistent with previous observations of a lower salivary $\mathrm{NO}_{3}{ }^{-}$uptake after oral $\mathrm{NO}_{3}{ }^{-}$consumption in smokers compared to non-smoking controls [44,45]. This antagonism of salivary $\mathrm{NO}_{3}{ }^{-}$uptake after $\mathrm{NO}_{3}{ }^{-}$supplementation is likely mediated by greater plasma and salivary $\left[\mathrm{SCN}^{-}\right]$in the smokers since it has been suggested that $\mathrm{NO}_{3}{ }^{-}$and $\mathrm{SCN}^{-}$share a common transporter for uptake into the salivary circulation and that $\mathrm{SCN}^{-}$has a higher affinity for salivary uptake than $\mathrm{NO}_{3}{ }^{-}$[36]. In support of a competitive inhibition of salivary $\mathrm{NO}_{3}^{-}$uptake by $\mathrm{SCN}^{-}$, the change in the salivary $\left[\mathrm{NO}_{3}{ }^{-}\right]$ between the CON and NIT conditions was negatively correlated with the salivary [ $\left.\mathrm{SCN}^{-}\right]$in $\mathrm{CON}$ in the smokers (figure 3). Further support for competition between $\mathrm{NO}_{3}{ }^{-}$and $\mathrm{SCN}^{-}$for passage into the salivary circulation is evidenced by the lower salivary [SCN$\left.{ }^{-}\right]$in NIT compared to CON in both the smokers (-33\%) and non-smokers $(-38 \%)$ in this study. Collectively, these findings lend support to the notion that $\mathrm{NO}_{3}{ }^{-}$and $\mathrm{SCN}^{-}$share a common salivary transporter(s), possibly sialin [54], and that $\mathrm{SCN}^{-}$can competitively inhibit salivary $\mathrm{NO}_{3}{ }^{-}$uptake.

Although salivary $\left[\mathrm{NO}_{3}{ }^{-}\right]$was lower after NIT in the smokers compared to the non-smokers, salivary $\left[\mathrm{NO}_{2}^{-}\right]$was not different between smokers and non-smokers after NIT. These 
observations are consistent with previous findings of a similar salivary $\left[\mathrm{NO}_{2}^{-}\right]$in smokers and non-smokers after $\mathrm{NO}_{3}{ }^{-}$ingestion in spite of a lower salivary $\left[\mathrm{NO}_{3}{ }^{-}\right.$] [44]. It has been reported that the $K_{\mathrm{m}}$ of the oral bacteria $\mathrm{NO}_{3}{ }^{-}$reductases for $\mathrm{NO}_{3}{ }^{-}$is $\sim 1000 \mu \mathrm{M}[55,56]$. Salivary $\left[\mathrm{NO}_{3}{ }^{-}\right]$increased to a mean concentration $7450 \mu \mathrm{M}$ after NIT in the non-smokers and a mean value of $3708 \mu \mathrm{M}$ in the smokers in this study. Therefore, it is possible that the similar salivary $\left[\mathrm{NO}_{2}^{-}\right]$after NIT in the smokers and non-smokers might be related to both groups obtaining a saturating salivary $\left[\mathrm{NO}_{3}{ }^{-}\right]$for the oral $\mathrm{NO}_{3}{ }^{-}$reductases after NIT. However, more recent studies have reported that increasing the salivary $\left[\mathrm{NO}_{3}{ }^{-}\right]$to a greater extent than achieved in the current study ( 12-16 mM) can lead to further increases in salivary $\left[\mathrm{NO}_{2}{ }^{-}\right](\sim 2.5 \mathrm{mM}$ vs. $\sim 1.5 \mathrm{mM}$ in the current study), at least in non-smokers $[47,53]$. These results challenge the previously reported $K_{\mathrm{m}}$ of the oral bacteria $\mathrm{NO}_{3}{ }^{-}$reductases for $\mathrm{NO}_{3}{ }^{-}[55,56]$. Therefore, further research is required to resolve the mechanisms than underlie the similar increase in salivary $\left[\mathrm{NO}_{2}{ }^{-}\right]$in spite of a lower increase in salivary $\left[\mathrm{NO}_{3}{ }^{-}\right]$after $\mathrm{NO}_{3}{ }^{-}$supplementation in smokers, and the $K_{\mathrm{m}}$ of the oral bacteria $\mathrm{NO}_{3}{ }^{-}$reductases for $\mathrm{NO}_{3}{ }^{-}$.

Circulating plasma $\left[\mathrm{NO}_{3}{ }^{-}\right]$and $\left[\mathrm{NO}_{2}^{-}\right]$were both increased compared to $\mathrm{CON}$ and PLA after NIT in non-smokers, as reported elsewhere [9,11-13,24,31,32,33,57]. However, despite plasma $\left[\mathrm{NO}_{3}{ }^{-}\right]$and $\left[\mathrm{NO}_{2}{ }^{-}\right]$also increasing above values observed in the CON condition in the smokers, plasma $\left[\mathrm{NO}_{3}{ }^{-}\right]$and $\left[\mathrm{NO}_{2}^{-}\right]$were only increased to $60 \%$ and $39 \%$ of the values observed in the non-smokers after NIT. It has been reported that smoking a single cigarette transiently lowers plasma $\left[\mathrm{NO}_{3}{ }^{-}\right]$and $\left[\mathrm{NO}_{2}^{-}\right]$for 60 minutes [58]. However, since our participants were asked to abstain from smoking for 3 hours prior to reporting to the laboratory, and since the expired [CO] was not different in the smokers across the experimental conditions, it is unlikely that the blunted increases in plasma $\left[\mathrm{NO}_{3}{ }^{-}\right]$and $\left[\mathrm{NO}_{2}{ }^{-}\right]$ after NIT in the smokers can be ascribed to the acute effects of smoking. Given that salivary $\mathrm{NO}_{3}{ }^{-}$uptake was lower in the smokers, the lower plasma $\left[\mathrm{NO}_{3}{ }^{-}\right]$after NIT in this group might have been a function of increased $\mathrm{NO}_{3}{ }^{-}$excretion in urine to offset excessive plasma $\mathrm{NO}_{3}{ }^{-}$ accumulation. The lower plasma $\left[\mathrm{NO}_{2}{ }^{-}\right]$after NIT in the smokers compared to the nonsmokers, in spite of a similar salivary $\left[\mathrm{NO}_{2}^{-}\right]$, might also be linked to increased $\mathrm{NO}_{2}{ }^{-}$ excretion. Alternatively, it is possible that the $\mathrm{SCN}^{-}$-catalysed reduction of $\mathrm{NO}_{2}{ }^{-}$to $\mathrm{NO}$ in the stomach [59] was increased in the smokers, which might have attenuated $\mathrm{NO}_{2}{ }^{-}$uptake into the systemic circulation. In addition, smokers have an elevated myloperoxidase activity in neutrophils [60], which has been reported to catalyse $\mathrm{NO}_{2}^{-}$oxidation [61] and might have contributed to the lower plasma $\left[\mathrm{NO}_{2}^{-}\right]$after NIT in the smokers. Finally, it has been 
suggested that cigarette smoking impairs NO generation through eNOS, by lowering eNOS expression [62] and/or promoting eNOS uncoupling [63], and that the chemical reduction of $\mathrm{NO}_{2}{ }^{-}$can compensate for the perturbed cardiovascular function associated with NOS dysfunction [64-66]. Therefore, the lower plasma $\left[\mathrm{NO}_{2}{ }^{-}\right]$after NIT in the smokers in this study might be reflective of an increased $\mathrm{NO}_{2}{ }^{-}$reduction to $\mathrm{NO}$ through xanthine oxidase [67] or other $\mathrm{NO}_{2}^{-}$reductases [30] as a compensatory mechanism for a potential shortfall in eNOS-derived NO.

Compared to PLA, systolic blood pressure was significantly lowered by $3 \mathrm{mmHg}$ after NIT in the normotensive non-smokers who participated in this study. These findings are consistent with several [9,11-15], but not all [e.g., 68], previous reports of lower blood pressure after NIT in normotensive non-smoking participants. In addition, we observed a significant negative correlation between the change in plasma $\left[\mathrm{NO}_{2}^{-}\right]$and the change in systolic blood pressure between the PLA and NIT conditions in the non-smokers, consistent with the effects of $\mathrm{NO}_{2}^{-}[28,29]$ or $\mathrm{NO}[30,57]$ on smooth muscle relaxation, and with previous reports of negative correlations between the changes in plasma $\left[\mathrm{NO}_{2}^{-}\right]$and blood pressure [57]. However, while NIT increased plasma $\left[\mathrm{NO}_{2}{ }^{-}\right]$, and therefore the potential for $\mathrm{O}_{2}$-independent NO generation [30], it is unclear whether the lowering of blood pressure is mediated through classical NO-cyclic guanosine monophosphate (cGMP) signalling. $\mathrm{NO}_{3}{ }^{-}$supplementation has been reported to increase plasma $\left[\mathrm{NO}_{2}^{-}\right]$and lower blood pressure in association with increased plasma [cGMP] in some studies [57], but recent evidence also suggests that the lowering of blood pressure following $\mathrm{NO}_{3}{ }^{-}$supplementation might be mediated by modulating renal physiology [69]. Therefore, the mechanisms that underlie the lowering of blood pressure after short-term $\mathrm{NO}_{3}{ }^{-}$supplementation requires further investigation.

In the smokers, blood pressure was not different between the NIT and PLA trials. It is important to note that the mean increase in plasma $\left[\mathrm{NO}_{2}{ }^{-}\right]$after ingesting $8.4 \mathrm{mmol}$ of $\mathrm{NO}_{3}^{-}-$ rich beetroot juice was $218 \mathrm{nM}$ in the smokers, which was only 39\% of the mean plasma $\left[\mathrm{NO}_{2}{ }^{-}\right]$observed in the non-smokers after NIT, and is comparable with the mean $220 \mathrm{nM}$ increase in plasma $\left[\mathrm{NO}_{2}{ }^{-}\right]$after ingesting only $4.2 \mathrm{mmol}$ of $\mathrm{NO}_{3}{ }^{-}$-rich beetroot juice in our previous dose-response study [13]. While the lack of a significant blood pressure reduction might be ascribed, at least in part, to a lower plasma $\left[\mathrm{NO}_{2}^{-}\right]$in smokers after NIT, systolic blood pressure but not diastolic or mean arterial blood pressures, was significantly lower after the ingestion of $4.2 \mathrm{mmol}$ of $\mathrm{NO}_{3}{ }^{-}$-rich beetroot juice in our previous dose-response study 
[13]. Smokers have been reported to exhibit increased plasma nitrotyrosine levels [70], potentially indicative of increased scavenging of NO by superoxide [71]. This suggests that the bioavailability of $\mathrm{NO}_{2}^{-}$-derived $\mathrm{NO}$, and the accompanying lowering of blood pressure, might be compromised in smokers at a given $\mathrm{NO}_{3}{ }^{-}$dose. Moreover, cigarette smoking is associated with heightened inflammatory, oxidative and nitrative stress, which contributes to vascular remodelling and biochemical dysfunction [72-74]. These negative effects on the vasculature might lower the responsiveness of the blood vessels to dilate at a given plasma $\left[\mathrm{NO}_{2}^{-}\right]$which could account for our findings of improved blood pressure in non-smokers, but not smokers, after short-term dietary $\mathrm{NO}_{3}{ }^{-}$supplementation.

It is well documented that hypertension [77] is an independent predictor of cardiovascular disease morbidity and mortality. The magnitude of systolic blood pressure reductions in this study would be expected to lower the incidence of stroke and ischemic heart disease [79]. These observations suggest that the blood pressure reductions after short-term NIT in nonsmokers might be expected to confer a lower risk for cardiovascular disease morbidity and adverse cardiovascular events. Conversely, and despite ingesting the same absolute $\mathrm{NO}_{3}{ }^{-}$ dose as the non-smokers, blood pressure was not lowered after NIT in the smokers. By suggesting that cigarette smokers might not improve blood pressure if they increase dietary $\mathrm{NO}_{3}{ }^{-}$intake, our data provide potential novel insights into the risk factors for cardiovascular disease morbidity in cigarette smokers. Since the attenuated effects of NIT on blood pressure appear to be linked, at least in part, to a $\mathrm{SCN}^{-}$-mediated perturbation to dietary $\mathrm{NO}_{3}{ }^{-}$ metabolism, and since circulating $\mathrm{SCN}^{-}$is increased dose-dependently with smoking status [43], it is possible that the antagonistic effects of $\mathrm{SCN}^{-}$on dietary $\mathrm{NO}_{3}{ }^{-}$metabolism and its associated physiological responses are even greater in individuals with a higher number of pack years than the light smokers ( $7 \pm 6$ pack years) who participated in this study. Similarly, since we instructed smokers to abstain from cigarette smoking for 3 hours prior to reporting to the laboratory, the potential for $\mathrm{NO}_{3}{ }^{-}$supplementation to offset the transient increase in blood pressure [80] and lowering of plasma $\left[\mathrm{NO}_{2}^{-}\right]$[58] was not explored in this study and could represent a positive effect of dietary $\mathrm{NO}_{3}{ }^{-}$supplementation in cigarette smokers. It is also important to stress that, although the findings of this study suggest that cigarette smokers might not improve blood pressure if they increase dietary $\mathrm{NO}_{3}{ }^{-}$intake, increased $\mathrm{NO}_{3}{ }^{-}$-rich vegetable consumption will provide other nutrients that can benefit human health $[2,3]$. Moreover, it is possible that increased $\mathrm{NO}_{3}{ }^{-}$intake might have improved aspects of health in smokers that were not investigated in this study or that cigarette smokers 
might need to consume a greater $\mathrm{NO}_{3}{ }^{-}$dose to lower blood pressure compared to their nonsmoking counterparts. Therefore, further research is required to assess the health outcomes and underlying mechanisms of compromised dietary $\mathrm{NO}_{3}{ }^{-}$metabolism in cigarette smokers.

\section{CONCLUSION}

In conclusion, salivary $\left[\mathrm{NO}_{3}{ }^{-}\right]$, plasma $\left[\mathrm{NO}_{3}{ }^{-}\right]$and plasma $\left[\mathrm{NO}_{2}{ }^{-}\right]$were lower by $\sim 50 \%$ in cigarette smokers compared to non-smoking controls after ingesting the same absolute $\mathrm{NO}_{3}{ }^{-}$ dose. This perturbation to dietary $\mathrm{NO}_{3}{ }^{-}$metabolism in cigarette smokers abolished the improvement in blood pressure that was observed in the non-smokers after $\mathrm{NO}_{3}{ }^{-}$ supplementation. These findings suggest that cigarette smokers are less likely to improve blood pressure if they were to increase dietary $\mathrm{NO}_{3}^{-}$intake. These observations might provide important novel insights into the mechanisms by which cigarette smoking predisposes to increased cardiovascular disease morbidity and mortality. 


\section{REFERENCES}

[1] Laslett, L. J.; Alagona, P. Jr; Clark, B. A. $3^{\text {rd }}$; Drozda, J. P. Jr; Saldivar, F.; Wilson, S. R.; Poe, C.; Hart, M. The worldwide environment of cardiovascular disease: prevalence, diagnosis, therapy, and policy issues: a report from the American College of Cardiology.

J Am Coll Cardiol. 60:S1-S49; 2012.

[2] Bazzano. L. A.; He, J.; Ogden, L. G.; Loria, C. M.; Vupputuri, S.; Myers, L.; Whelton, P. K. Fruit and vegetable intake and risk of cardiovascular disease in US adults: the first National Health and Nutrition Examination Survey Epidemiologic Follow-up Study. Am J Clin Nutr. 76:93-99; 2002.

[3] Bazzano, L. A.; Serdula, M. K.; Liu, S. Dietary intake of fruits and vegetables and risk of cardiovascular disease. Curr Atheroscler Rep. 5:492-499; 2003.

[4] Appel, L. J.; Moore, T. J.; Obarzanek, E.; Vollmer, W. M.; Svetkey, L.P.; Sacks, F. M.; Bray, G.A.; Vogt, T. M.; Cutler, J. A.; Windhauser, M.M.; Lin, P.H.; Karanja, N. A clinical trial of the effects of dietary patterns on blood pressure. DASH Collaborative Research Group. N Engl J Med. 336:1117-1124, 1997.

[5] NHS Choices. Why 5 a Day? 2013. Retrieved 25 ${ }^{\text {th }}$ August 2015 from http://www.nhs.uk/Livewell/5ADAY/Pages/5ADAYhome.aspx

[6] EUFIC. Fruit and vegetable consumption in Europe - do Europeans get enough? 2012 Retrieved 25 ${ }^{\text {th }}$ August 2015 from http://www.eufic.org/article/en/expid/Fruit-vegetableconsumption-Europe/

[7] Hord, N. G.; Tang, Y.; Bryan, N. S. Food sources of nitrates and nitrites: the physiologic context for potential health benefits. Am J Clin Nutr. 90:1-10; 2009.

[8] Kapil, V.; Webb, A.J.; Ahluwalia, A. Inorganic nitrate and the cardiovascular system. Heart. 96:1703-1709; 2010.

[9] Ashworth, A.; Mitchell, K.; Blackwell, J. R.; Vanhatalo, A.; Jones, A.M. High-nitrate vegetable diet increases plasma nitrate and nitrite concentrations and reduces blood pressure in healthy women. Public Health Nutr. 16:1-10; 2015.

[10] Ysart, G.; Miller, P.; Barrett, G.; Farrington, D.; Lawrance, P.; Harrison, N. Dietary exposures to nitrate in the UK. Food Addit Contam. 16:521-532; 1999.

[11] Webb, A. J.; Patel, N.; Loukogeorgakis, S.; Okorie, M.; Aboud, Z.; Misra, S.; Rashid, R.; Miall, P.; Deanfield, J.; Benjamin, N.; MacAllister, R.; Hobbs, A. J.; Ahluwalia, A. Acute blood pressure lowering, vasoprotective, and antiplatelet properties of dietary nitrate via bioconversion to nitrite. Hypertension. 51:784-790; 2008. 
[12] Bailey, S. J.; Winyard, P,; Vanhatalo, A.; Blackwell, J. R.; DiMenna, F. J.; Wilkerson, D. P.; Tarr, J.; Benjamin, N.; Jones, A. M. Dietary nitrate supplementation reduces the $\mathrm{O}_{2}$ cost of low-intensity exercise and enhances tolerance to high-intensity exercise in humans. $J$ Appl Physiol. 107:1144-1155; 2009.

[13] Wylie, L. J.; Kelly, J.; Bailey, S. J.; Blackwell, J. R.; Skiba, P. F.; Winyard, P. G.; Jeukendrup, A. E.; Vanhatalo, A.; Jones, A. M. Beetroot juice and exercise: pharmacodynamic and dose-response relationships. J Appl Physiol. 115:325-336; 2013.

[14] Jovanovski, E.; Bosco, L.; Khan, K.; Au-Yeung, F.; Ho, H.; Zurbau, A.; Jenkins, A. L.; Vuksan, V. Effect of Spinach, a High Dietary Nitrate Source, on Arterial Stiffness and Related Hemodynamic Measures: A Randomized, Controlled Trial in Healthy Adults. Clin Nutr Res. 4:160-167; 2015.

[15] Liu, A. H.; Bondonno, C. P.; Croft, K. D.; Puddey, I. B.; Woodman, R. J.; Rich, L.; Ward, N. C.; Vita, J. A.; Hodgson, J. M. Effects of a nitrate-rich meal on arterial stiffness and blood pressure in healthy volunteers. Nitric Oxide. 35:123-130; 2013.

[16] Kelly, J.; Fulford, J.; Vanhatalo, A.; Blackwell, J.R.; French, O.; Bailey, S. J.; Gilchrist, M.; Winyard, P. G.; Jones, A. M. Effects of short-term dietary nitrate supplementation on blood pressure, $\mathrm{O}_{2}$ uptake kinetics, and muscle and cognitive function in older adults. Am J Physiol Regul Integr Comp Physiol. 304:73-83; 2013.

[17] Rammos, C.; Hendgen-Cotta, U. B.; Sobierajski, J.; Bernard, A.; Kelm, M.; Rassaf, T. Dietary nitrate reverses vascular dysfunction in older adults with moderately increased cardiovascular risk. J Am Coll Cardiol. 63:1584-1585; 2014.

[18] Kapil, V.; Khambata, R.S.; Robertson, A.; Caulfield, M.J.; Ahluwalia, A. Dietary nitrate provides sustained blood pressure lowering in hypertensive patients: a randomized, phase 2, double-blind, placebo-controlled study. Hypertension. 65:320-327; 2015.

[19] Kenjale, A.A.; Ham, K. L.; Stabler, T.; Robbins, J. L.; Johnson, J. L.; Vanbruggen, M.; Privette, G.; Yim, E.; Kraus, W. E.; Allen, J. D. Dietary nitrate supplementation enhances exercise performance in peripheral arterial disease. J Appl Physiol. 110:1582-1591; 2011.

[20] Zamani, P.; Rawat, D.; Shiva-Kumar, P.; Geraci, S.; Bhuva, R.; Konda, P.; Doulias, P. T.; Ischiropoulos, H.; Townsend, R. R.; Margulies, K. B.; Cappola, T. P.; Poole, D.C.; Chirinos, J. A. Effect of inorganic nitrate on exercise capacity in heart failure with preserved ejection fraction. Circulation. 131:371-380; 2015.

[21] Spiegelhalder. B.; Eisenbrand, G.; Preussmann, R. Influence of dietary nitrate on nitrite content of human saliva: possible relevance to in vivo formation of $\mathrm{N}$-nitroso compounds. Food Cosmet Toxicol. 14:545-548; 1976.

[22] Tannenbaum, S. R.; Weisman, M.; Fett, D. The effect of nitrate intake on nitrite formation in human saliva. Food Cosmet Toxicol. 14:549-552; 1976.

[23] Duncan, C.; Dougall, H.; Johnston, P.; Green, S.; Brogan, R.; Leifert, C.; Smith, L.; Golden, M.; Benjamin, N. Chemical generation of nitric oxide in the mouth from the enterosalivary circulation of dietary nitrate. Nat Med. 1:546-551; 1995. 
[24] Lundberg, J. O.; Govoni, M. Inorganic nitrate is a possible source for systemic generation of nitric oxide. Free Radic Biol Med. 37:395-400; 2004.

[25] Lundberg, J. O.; Weitzberg, E.; Cole, J. A.; Benjamin, N. Nitrate, bacteria and human health. Nat Rev Microbiol. 2:593-602; 2004.

[26] Benjamin, N.; O'Driscoll, F.; Dougall, H.; Duncan, C.; Smith, L.; Golden, M.; McKenzie, H. Stomach NO synthesis. Nature. 368:502; 1994.

[27] Lundberg, J. O.; Weitzberg, E.; Lundberg, J. M.; Alving, K. Intragastric nitric oxide production in humans: measurements in expelled air. Gut. 35:1543-1546; 1994.

[28] Bryan, N. S.; Fernandez, B. O.; Bauer, S. M.; Garcia-Saura, M. F.; Milsom, A. B.; Rassaf, T.; Maloney, R. E.; Bharti, A.; Rodriguez, J.; Feelisch, M. Nitrite is a signaling molecule and regulator of gene expression in mammalian tissues. Nat Chem Biol. 1:290-297; 2005.

[29] Alzawahra, W. F.; Talukder, M. A,; Liu, X.; Samouilov, A.; Zweier, J. L. Heme proteins mediate the conversion of nitrite to nitric oxide in the vascular wall. Am J Physiol Heart Circ Physiol. 295:499-508; 2008.

[30] van Faassen, E. E.; Bahrami, S.; Feelisch, M.; Hogg, N.; Kelm, M.; Kim-Shapiro, D. B.; Kozlov, A. V.; Li, H.; Lundberg, J. O.; Mason, R.; Nohl, H.; Rassaf, T.; Samouilov, A.; Slama-Schwok, A.; Shiva, S.; Vanin, A. F.; Weitzberg, E.; Zweier, J.; Gladwin, M. T. Nitrite as regulator of hypoxic signaling in mammalian physiology. Med Res Rev. 29:683-741; 2009.

[31] Bailey, S. J.; Fulford, J.; Vanhatalo, A.; Winyard, P. G.; Blackwell, J. R.; DiMenna, F. J.; Wilkerson, D. P.; Benjamin, N.; Jones, A. M. Dietary nitrate supplementation enhances muscle contractile efficiency during knee-extensor exercise in humans. J Appl Physiol. 109:135-148; 2010.

[32] Larsen, F. J.; Schiffer, T. A.; Borniquel, S.; Sahlin, K.; Ekblom, B.; Lundberg, J. O.; Weitzberg, E. Dietary inorganic nitrate improves mitochondrial efficiency in humans. Cell Metab. 13:149-159; 2011.

[33] Vanhatalo, A.; Bailey, S. J.; Blackwell, J. R.; DiMenna, F. J.; Pavey, T. G.; Wilkerson, D. P.; Benjamin, N.; Winyard, P. G.; Jones, A. M. Acute and chronic effects of dietary nitrate supplementation on blood pressure and the physiological responses to moderate-intensity and incremental exercise. Am J Physiol Regul Integr Comp Physiol. 299:1121-1131; 2010.

[34] Jansson, E.A.; Huang, L.; Malkey, R.; Govoni, M.; Nihlén, C.; Olsson, A.; Stensdotter, M.; Petersson, J.; Holm, L.; Weitzberg, E.; Lundberg, J. O. A mammalian functional nitrate reductase that regulates nitrite and nitric oxide homeostasis. Nat Chem Biol. 4:411-417; 2008.

[35] Lundberg, J.O.; Weitzberg, E. NO-synthase independent NO generation in mammals. Biochem Biophys Res Commun. 396:39-45; 2010. 
[36] Edwards, D. A.; Fletcher, K.; Rowlands, E. N. Antagonism between perchlorate, iodide, thiocyanate, and nitrate for secretion in human saliva; analogy with the iodide trap of the thyroid. Lancet. 266:498-499; 1954.

[37] Ockene, I.S.; Miller, N. H. Cigarette smoking, cardiovascular disease, and stroke: a statement for healthcare professionals from the American Heart Association. American Heart Association Task Force on Risk Reduction. Circulation. 96:3243-3247; 1997.

[38] US Department of Health and Human Services. How Tobacco Smoke Causes Disease: The Biology and Behavioral Basis for Smoking-Attributable Disease: A Report of the Surgeon General; 2010

[39] WHO. WHO global report: mortality attributable to tobacco. 2012. Retrieved $25^{\text {th }}$ August 2015 from http://www.who.int/tobacco/publications/surveillance/rep_mortality_attributable/en/

[40] Nelson, D. E.; Kirkendall, R. S.; Lawton, R. L.; Chrismon, J. H.; Merritt, R. K.; Arday, D. A.; Giovino, G. A. Surveillance for smoking-attributable mortality and years of potential life lost, by state--United States, 1990. MMWR CDC Surveill Summ. 43:1-8; 1994.

[41] WHO. Global status report on noncommunicable diseases. 2014. Retrieved $25^{\text {th }}$ August 2015 from http://www.who.int/nmh/publications/ncd-status-report-2014/en/

[42] Nagahara, N.; Ito, T.; Minami, M. Mercaptopyruvate sulfurtransferase as a defense against cyanide toxication: molecular properties and mode of detoxification. Histol Histopathol. 14:1277-1286; 1999.

[43] Tsuge, K., Kataoka, M.; Seto, Y. Cyanide and Thiocyanate Levels in Blood and Saliva of Healthy Adult Volunteers. J. Health Sci. 46:343-350; 2000.

[44] Ladd, K. F.; Newmark, H. L.; Archer, M. C. N-nitrosation of proline in smokers and nonsmokers. J Natl Cancer Inst. 73:83-87; 1984.

[45] Knight, T.M.; Forman, D.; Al-Dabbagh, S. A.; Doll, R. Estimation of dietary intake of nitrate and nitrite in Great Britain. Food Chem Toxicol. 25:277-285; 1987.

[46] Baecke, J. A.; Burema, J.; Frijters, J. E. A short questionnaire for the measurement of habitual physical activity in epidemiological studies. Am J Clin Nutr. 36:936-942; 1982.

[47] Govoni, M.; Jansson, E. A.; Weitzberg, E.; Lundberg, J. O. The increase in plasma nitrite after a dietary nitrate load is markedly attenuated by an antibacterial mouthwash. Nitric Oxide. 19:333-337; 2008.

[48] Maliszewski, T. F.; Bass, D. E. True and apparent thiocyanate in body fluids of smokers and nonsmokers. J Appl Physiol. 8:289-91; 1955.

[49] Abueg, F. R.; Colletti, G.; Rizzo, A. A.; The saliva thiocyanate analysis: a methodological extension and its relationship to $\mathrm{CO}$ and self-report in moderate smokers. Addict Behav. 11:55-58; 1986. 
[50] Fortmann, S.P.; Rogers, T.; Vranizan, K.; Haskell, W. L.; Solomon, D. S.; Farquhar, J. W. Indirect measures of cigarette use: expired-air carbon monoxide versus plasma thiocyanate. Prev Med. 13:127-135; 1984.

[51] Biglan, A.; Gallison, C.; Ary, D.; Thompson, R. Expired air carbon monoxide and saliva thiocyanate: relationships to self-reports of marijuana and cigarette smoking. Addict Behav. 10:137-144; 1985.

[52] Stookey, G.K.; Katz, B. P.; Olson, B. L.; Drook, C. A.; Cohen, S. J. Evaluation of biochemical validation measures in determination of smoking status. J Dent Res. 66:1597$1601 ; 1987$.

[53] Woessner, M.; Smoliga, J. M,; Tarzia, B.; Stabler, T.; Van Bruggen, M.; Allen, J. D. A stepwise reduction in plasma and salivary nitrite with increasing strengths of mouthwash following a dietary nitrate load. Nitric Oxide. 54:1-7; 2016

[54] Qin, L.; Liu, X.; Sun, Q.; Fan, Z.; Xia, D.; Ding, G.; Ong, H. L.; Adams, D.; Gahl, W. A.; Zheng, C.; Qi, S.; Jin, L.; Zhang, C.; Gu, L.; He, J.; Deng, D.; Ambudkar, I. S.; Wang, S. Sialin (SLC17A5) functions as a nitrate transporter in the plasma membrane. Proc Natl Acad Sci U S A. 109:13434-13439; 2012.

[55] Li, H.; Duncan, C.; Townend, J.; Killham, K.; Smith, L. M.; Johnston, P.; Dykhuizen, R.; Kelly, D.; Golden, M.; Benjamin, N.; Leifert, C. Nitrate-reducing bacteria on rat tongues. Appl Environ Microbiol. 63:924-930; 1997.

[56] Bojić, D. V.; Bojić, A. L.; Perović, J. M. The effects of dietary nitrate, pH and temperature on nitrate reduction in the human oral cavity. Facta Universitatis Series : Physics, Chemistry and Technology. 3:53-60; 2004.

[57] Kapil, V.; Milsom, A.B.; Okorie, M.; Maleki-Toyserkani, S.; Akram, F.; Rehman, F.; Arghandawi, S.; Pearl, V.; Benjamin, N.; Loukogeorgakis, S.; Macallister, R.; Hobbs, A. J.; Webb, A. J.; Ahluwalia, A. Inorganic nitrate supplementation lowers blood pressure in humans: role for nitrite-derived NO. Hypertension. 56:274-281; 2010.

[58] Tsuchiya, M.; Asada, A.; Kasahara, E.; Sato, E. F.; Shindo, M.; Inoue, M. Smoking a single cigarette rapidly reduces combined concentrations of nitrate and nitrite and concentrations of antioxidants in plasma. Circulation. 105:1155-1157; 2002.

[59] Iijima, K.; Fyfe, V.; McColl, K. E. Studies of nitric oxide generation from salivary nitrite in human gastric juice. Scand J Gastroenterol. 38:246-252; 2003.

[60] Loke, W.M.; Lam, K. M.; Chong, W. L.; Chew, S. E.; Quek, A. M.; Lim, E. Ch.; Seet, R. C. Products of 5-lipoxygenase and myeloperoxidase activities are increased in young male cigarette smokers. Free Radic Res. 46:1230-1237; 2012.

[61] Burner, U.; Furtmuller, P. G.; Kettle, A. J.; Koppenol, W. H.; Obinger, C. Mechanism of reaction of myeloperoxidase with nitrite. J Biol Chem. 275:20597-20601; 2000. 
[62] Barberà, J. A.; Peinado, V. I.; Santos, S.; Ramirez, J.; Roca, J.; Rodriguez-Roisin, R. Reduced expression of endothelial nitric oxide synthase in pulmonary arteries of smokers. Am J Respir Crit Care Med. 164:709-713; 2001.

[63] Zhang, W. Z.; Venardos, K.; Chin-Dusting, J.; Kaye D. M. Adverse effects of cigarette smoke on NO bioavailability: role of arginine metabolism and oxidative stress. Hypertension. 48:278-285; 2006.

[64] Bryan, N. S.; Calvert, J. W.; Gundewar, S.; Lefer, D. J. Dietary nitrite restores NO homeostasis and is cardioprotective in endothelial nitric oxide synthase-deficient mice. Free Radic Biol Med. 45:468-474; 2008.

[65] Carlström, M.; Larsen, F. J.; Nyström, T.; Hezel, M.; Borniquel, S.; Weitzberg, E.; Lundberg, J. O. Dietary inorganic nitrate reverses features of metabolic syndrome in endothelial nitric oxide synthase-deficient mice. Proc Natl Acad Sci U S A. 107:1771617720; 2010.

[66] Ferguson, S. K.; Glean, A. A.; Holdsworth, C. T.; Wright, J. L.; Fees, A. J.; Colburn, T. D.; Stabler, T.; Allen, J. D.; Jones, A. M.; Musch, T. I.; Poole, D. C. Skeletal Muscle Vascular Control During Exercise: Impact of Nitrite Infusion During Nitric Oxide Synthase Inhibition in Healthy Rats. J Cardiovasc Pharmacol Ther. In press; 2015.

[67] Zhang, Z.; Naughton, D.; Winyard, P. G.; Benjamin, N.; Blake, D. R.; Symons, M. C. Generation of nitric oxide by a nitrite reductase activity of xanthine oxidase: a potential pathway for nitric oxide formation in the absence of nitric oxide synthase activity. Biochem Biophys Res Commun. 249:767-772; 1998.

[68] McDonagh, S. T.; Wylie, L. J.; Winyard, P. G.; Vanhatalo, A.; Jones, A. M. The Effects of Chronic Nitrate Supplementation and the Use of Strong and Weak Antibacterial Agents on Plasma Nitrite Concentration and Exercise Blood Pressure. Int J Sports Med. 36:1177-1185; 2015.

[69] Gao, X.; Yang, T.; Liu, M.; Peleli, M.; Zollbrecht, C.; Weitzberg, E.; Lundberg, J. O,; Persson, A. E.; Carlström, M. NADPH oxidase in the renal microvasculature is a primary target for blood pressure-lowering effects by inorganic nitrate and nitrite. Hypertension. 65:161-170; 2015.

[70] Petruzzelli, S.;, Puntoni, R.; Mimotti, P.; Pulerà, N.; Baliva, F.; Fornai, E.; Giuntini, C. Plasma 3-nitrotyrosine in cigarette smokers. Am J Respir Crit Care Med. 156:1902-1907; 1997.

[71] Guzik, T. J.; West, N. E.; Pillai, R.; Taggart, D. P.; Channon, K. M. Nitric oxide modulates superoxide release and peroxynitrite formation in human blood vessels. Hypertension. 39:1088-1094; 2002.

[72] Guo, X.; Oldham, M. J.; Kleinman, M.T.; Phalen, R. F.; Kassab, G. S. Effect of cigarette smoking on nitric oxide, structural, and mechanical properties of mouse arteries. Am J Physiol Heart Circ Physiol. 291:2354-2361; 2006. 
[73] Edirisinghe, I.; Arunachalam, G.; Wong, C.; Yao, H.; Rahman, A.; Phipps, R. P.; Jin, Z. G,; Rahman, I. Cigarette-smoke-induced oxidative/nitrosative stress impairs VEGF- and fluid-shear-stress-mediated signaling in endothelial cells. Antioxid Redox Signal. 12:13551369; 2010.

[74] Tomiyama, H.; Hashimoto, H.; Tanaka, H.; Matsumoto, C.; Odaira, M.; Yamada, J.; Yoshida, M.; Shiina, K.; Nagata, M.; Yamashina, A. Continuous smoking and progression of arterial stiffening: a prospective study. J Am Coll Cardiol. 55:1979-1987; 2010.

[75] Allen, J. D.; Stabler, T.; Kenjale, A.; Ham, K. L.; Robbins, J. L.; Duscha, B. D.; Dobrosielski, D. A.; Annex, B. H. Plasma nitrite flux predicts exercise performance in peripheral arterial disease after 3months of exercise training. Free Radic Biol Med. 49:11384411; 2010.

[76] Totzeck, M.; Hendgen-Cotta, U. B.; Rammos, C.; Frommke, L. M.; Knackstedt, C.; Predel, H. G.; Kelm, M.; Rassaf, T. Higher endogenous nitrite levels are associated with superior exercise capacity in highly trained athletes. Nitric Oxide. 27:75-81; 2012.

[77] Franklin, S. S.; Wong, N. D. Hypertension and cardiovascular disease: contributions of the framingham heart study. Glob Heart. 8:49-57; 2013.

[78] Blair, S. N.; Kohl, H.W. $3^{\text {rd }}$; Barlow, C. E.; Paffenbarger, R. S. Jr.; Gibbons, L. W.; Macera, C. A. Changes in physical fitness and all-cause mortality. A prospective study of healthy and unhealthy men. JAMA. 273:1093-1098; 1995.

[79] He, F. J.; MacGregor, G. A. How far should salt intake be reduced? Hypertension. 42: 1093-1099; 2003.

[80] Kubozono, T.; Miyata, M.; Ueyama, K.; Hamasaki, S.; Kusano, K.; Kubozono, O.; Tei, C. Acute and chronic effects of smoking on arterial stiffness. Circ J. 75:698-702; 2011. 


\section{Figure Legends}

Figure 1: Mean salivary (upper panel) and plasma (lower panel) thiocyanate concentrations ([SCN$\left.\left.{ }^{-}\right]\right)$following no dietary supplementation ( $\left.\mathrm{CON}\right)$, supplementation with nitrate-depleted beetroot juice (PLA) and supplementation with nitrate-rich beetroot juice (NIT) in smokers and non-smokers. The filled bars represent the group mean \pm SEM responses in the CON, PLA and NIT conditions in non-smokers, while the open bars represent the group mean \pm SEM responses in the CON, PLA and NIT conditions in smokers. \# indicates significantly different from the smokers in the same experimental * indicates significantly different from responses in CON and PLA. Note condition. the higher mean salivary and plasma [SCN$\left.{ }^{-}\right]$in smokers in all experimental conditions and the lower salivary [ $\left.\mathrm{SCN}^{-}\right]$in NIT compared to CON and PLA in both smokers and no-smokers.

Figure 2: Mean salivary and plasma nitrate $\left(\left[\mathrm{NO}_{3}{ }^{-}\right]\right.$) and nitrite $\left(\left[\mathrm{NO}_{2}{ }^{-}\right]\right)$concentrations following no dietary supplementation (CON), supplementation with nitrate-depleted beetroot juice (PLA) and supplementation with nitrate-rich beetroot juice (NIT) in smokers and nonsmokers. Salivary $\left[\mathrm{NO}_{3}{ }^{-}\right]$responses are shown in the upper left panel, salivary $\left[\mathrm{NO}_{2}{ }^{-}\right]$ responses are shown in the upper right panel, plasma $\left[\mathrm{NO}_{3}{ }^{-}\right]$responses are shown in the lower left panel and salivary $\left[\mathrm{NO}_{2}{ }^{-}\right]$responses are shown in the lower right panel. The filled bars represent the group mean \pm SEM responses in the CON, PLA and NIT conditions in non-smokers, while the open bars represent the group mean \pm SEM responses in the CON, PLA and NIT conditions in smokers. \# indicates significantly different from the smokers in the same experimental condition. * indicates significantly different from responses in CON and PLA. Note the significant increases in mean salivary and plasma $\left[\mathrm{NO}_{3}{ }^{-}\right]$and $\left[\mathrm{NO}_{2}^{-}\right]$with NIT supplementation in both smokers and non-smokers and that the increases in the salivary $\left[\mathrm{NO}_{3}{ }^{-}\right]$and plasma $\left[\mathrm{NO}_{3}{ }^{-}\right]$and $\left[\mathrm{NO}_{2}{ }^{-}\right]$were lower following oral consumption of the same NIT dose in smokers compared to non-smokers.

Figure 3: The relationship between salivary thiocyanate concentration ([SCN$\left.{ }^{-}\right]$) with no supplementation $(\mathrm{CON})$ and the change $(\Delta)$ in salivary nitrate concentration ([ $\left.\left.\mathrm{NO}_{3}^{-}\right]\right)$between the CON and NIT conditions in smokers. Note that the salivary [ $\left.\mathrm{SCN}^{-}\right]$in $\mathrm{CON}$ was negatively correlated with $\Delta \mathrm{CON}-\mathrm{NIT}$ salivary $\left[\mathrm{NO}_{3}{ }^{-}\right]$. 
Figure 4: The individual changes in systolic, diastolic and mean arterial blood pressures following supplementation with nitrate-depleted beetroot juice (PLA) and supplementation with nitrate-rich beetroot juice (NIT) in smokers and non-smokers. * indicates significantly different from responses in PLA. 
Table 1. Resting supine blood pressure measures following nitrate-depleted beetroot juice supplementation (PLA) and nitrate-rich beetroot juice supplementation (NIT) in smokers and non-smokers.

\begin{tabular}{|l|c|c|}
\hline & \multicolumn{2}{|c|}{ Smokers } \\
\hline & PLA & NIT \\
\hline Systolic blood pressure (mmHg) & $109 \pm 8$ & $110 \pm 7$ \\
\hline Diastolic blood pressure (mmHg) & $59 \pm 6$ & $59 \pm 5$ \\
\hline Mean arterial pressure (mmHg) & $79 \pm 5$ & $79 \pm 4$ \\
\hline & \multicolumn{2}{|c|}{ Non-smokers } \\
\hline & PLA & NIT \\
\hline & $103 \pm 8$ & $100 \pm 10^{*}$ \\
\hline Systolic blood pressure (mmHg) & $59 \pm 4$ & $58 \pm 8$ \\
\hline Diastolic blood pressure (mmHg) & $76 \pm 6$ & $74 \pm 9$ \\
\hline Mean arterial pressure (mmHg) & & \\
\hline
\end{tabular}

Values are presented as the mean \pm SD. ${ }^{*}=$ significantly different from PLA $(P<0.05)$. 

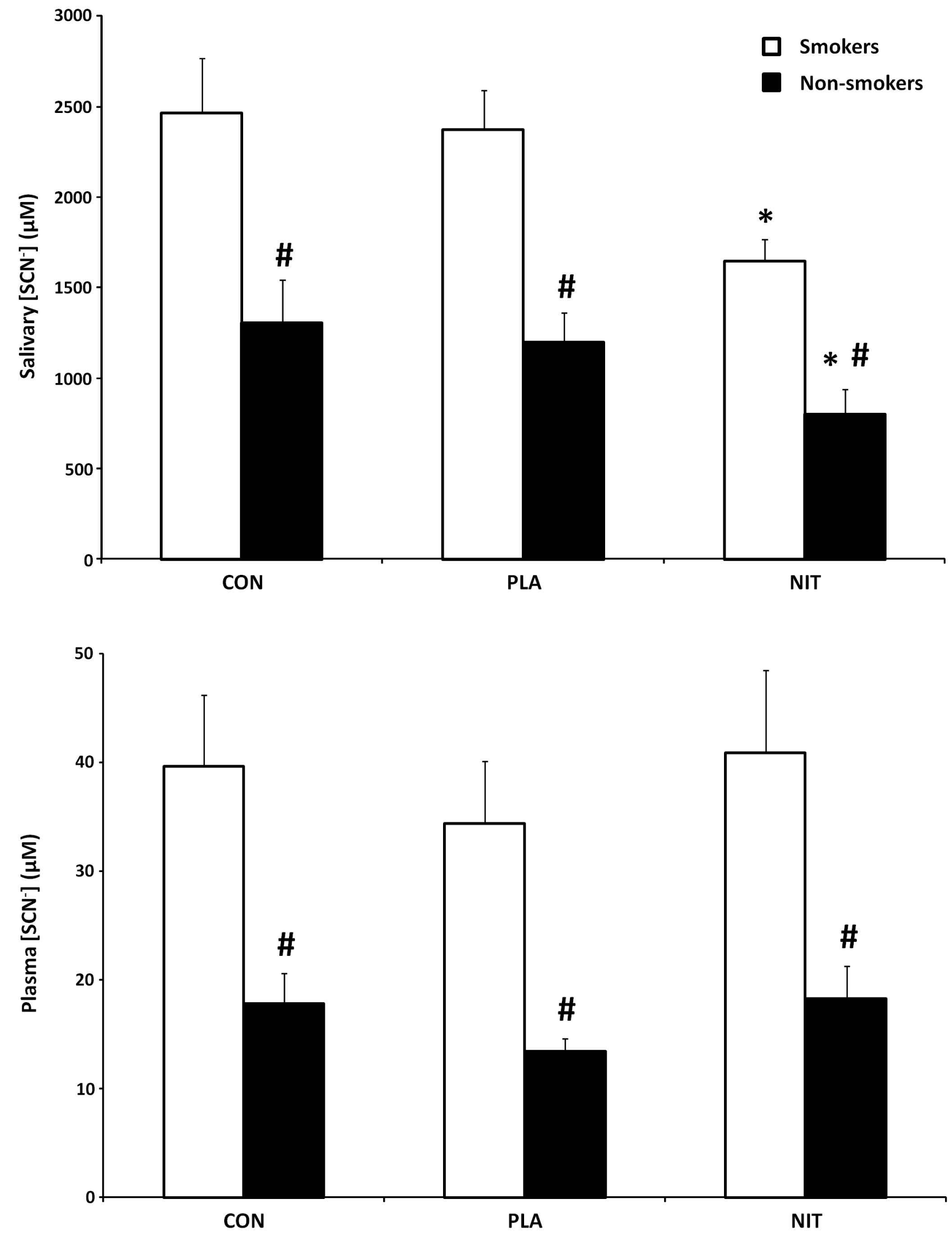

Figure 1 

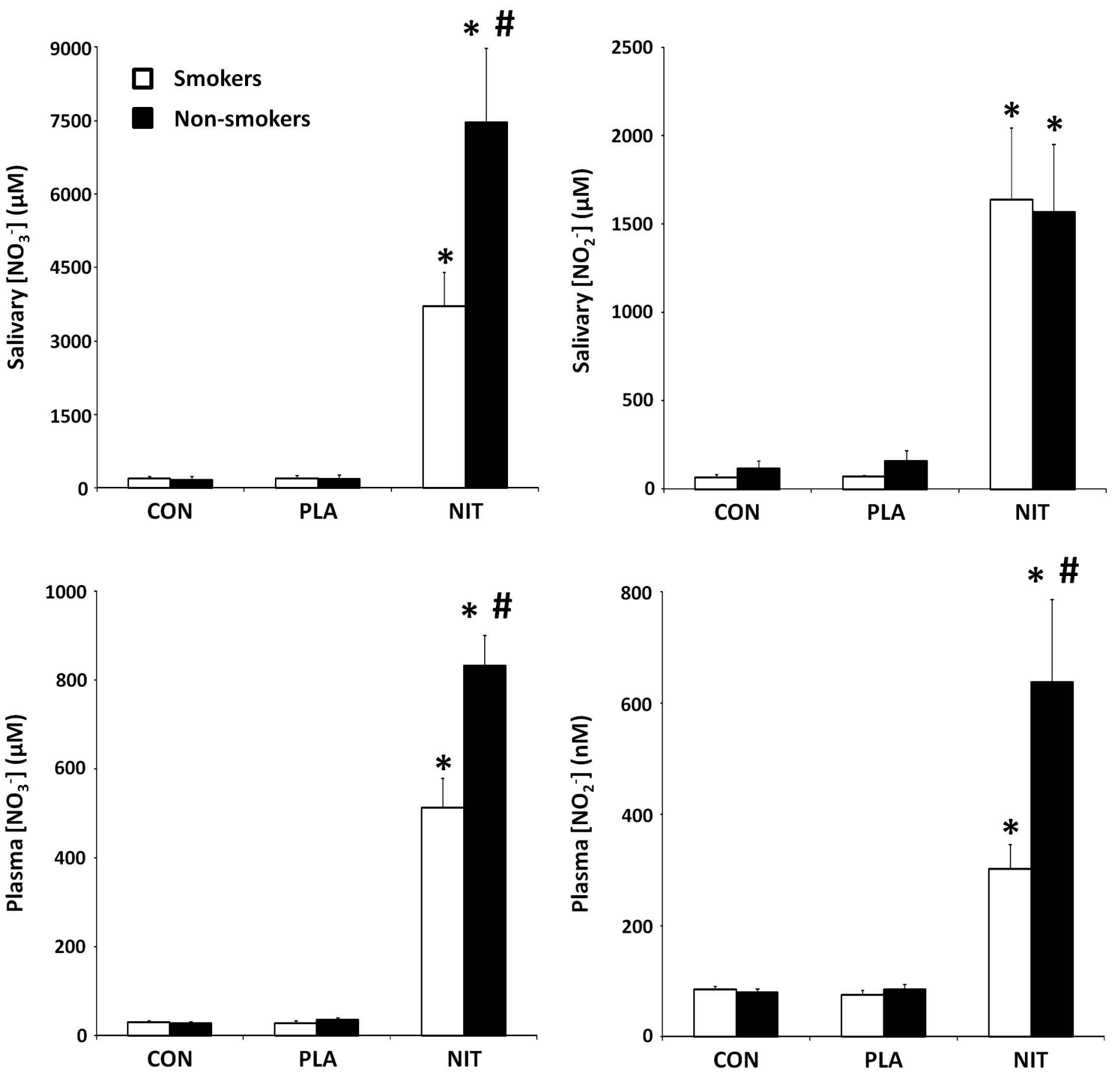

Figure 2 


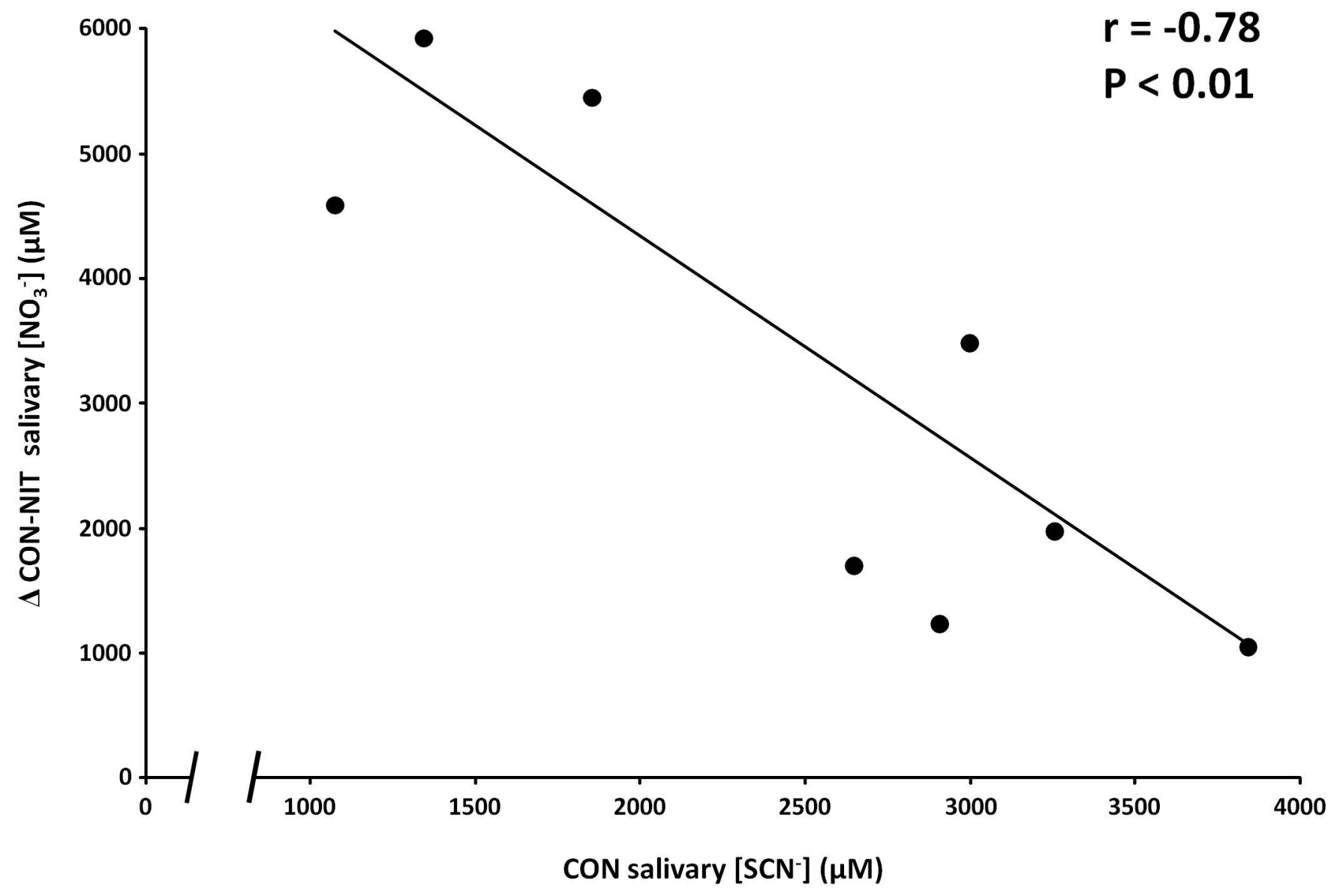

Figure 3 

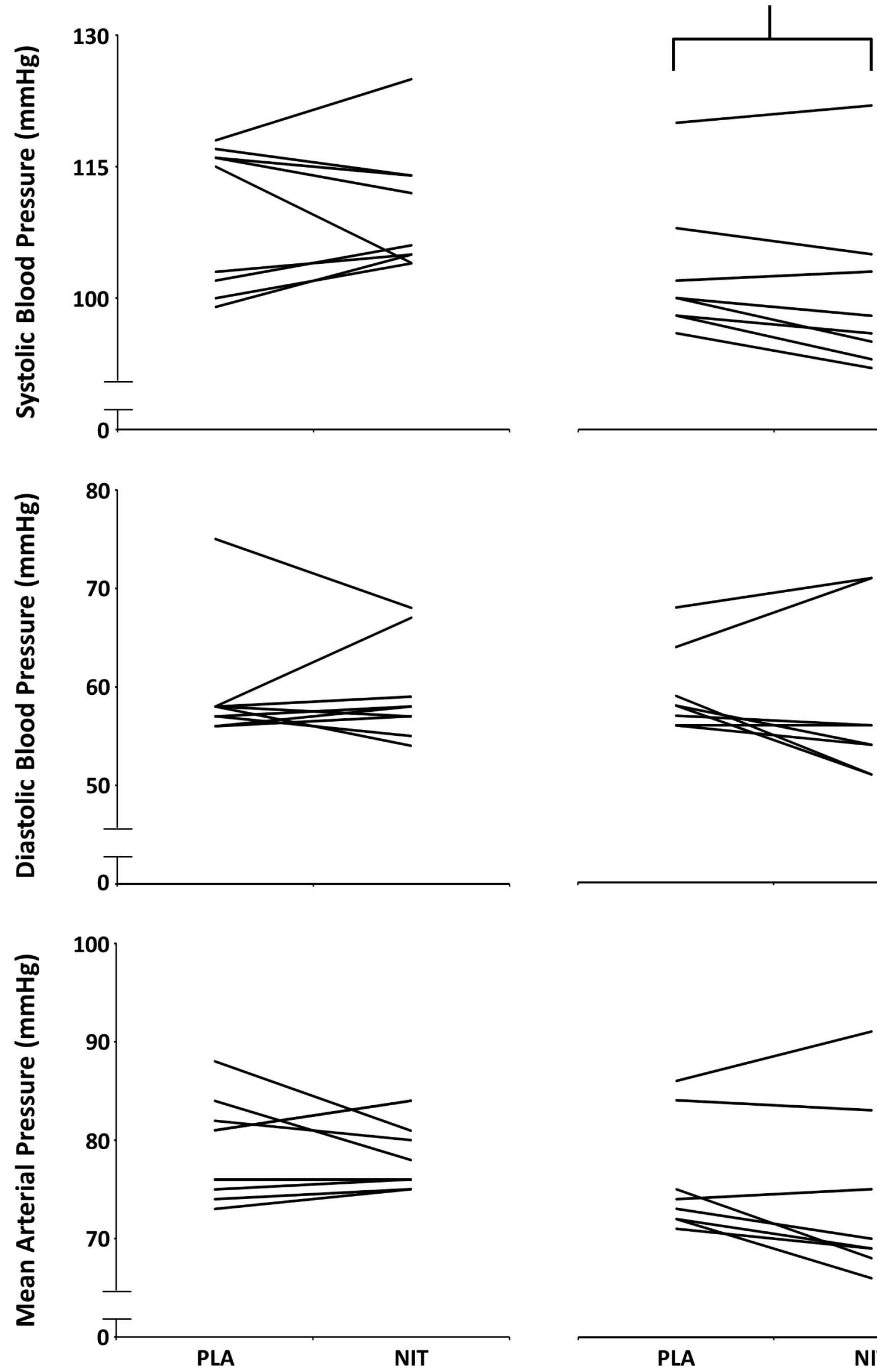

Figure 4
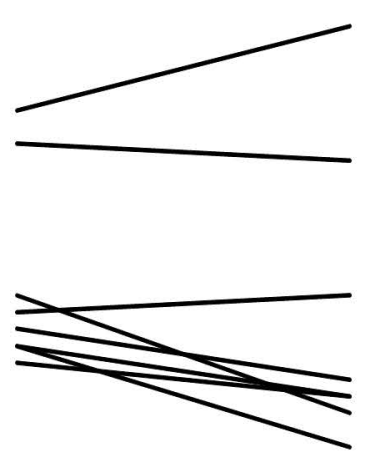

PLA NIT Non-smokers 